\title{
DOSSIÊ: MUSEUS DE ARTE CONTEMPORÂNEA NO SÉCULO 21
}

\author{
Ana Gonçalves Magalhães \\ Professora Livre-Docente \\ Museu de Arte Contemporânea da Universidade de São Paulo
}

(MAC USP)

As duas primeiras décadas do século $2 \mathrm{I}$ anunciaram grandes transformações no mundo, principalmente considerando-se que o novo século se abriu com aquele que tem sido considerado o maior ataque terrorista da história contemporânea (II de setembro de 200 I). Paralelamente, a internet alcançou todos os territórios do planeta, servindo tanto para a promoção do conhecimento e da cultura, quanto para o terror - tal como revelado por ataques terroristas subsequentes que se iniciaram com o uso de smartphones.Além disso, o caráter talvez mais marcante da nossa época seja a da emergência da economia financeira como paradigma para todas as instâncias da vida das sociedades, inclusive do mundo da arte. Esses acontecimentos, dentro tantos outros, tem fomentado a arte contemporânea e a imaginação dos artistas.

Ao mesmo tempo, já há quase 50 anos os modos como interagimos e frequentamos a arte contemporânea se modificaram radicalmente. Os anos 1960 assistiram a um grande debate em torno da necessidade de reformulação dos museus de arte moderna, e de documentar e preservar as novas práticas artísticas, inauguradas já na metade dos anos 1950, e que levaram críticos e outros profissionais da arte a repensar a concepção de museu de arte, de modo a incorporar as práticas processuais emergentes. A nova concepção de museu - ou o museu de arte contemporânea - nasceria desse debate. $O$ caso modelar é o do Centro Georges Pompidou, inaugurado há exatos 40 anos: um prédio de caráter industrial, um átrio de acolhimento do público como um grande fórum de debates e um espaço para mostras temporárias, e os andares superiores de apresentação de seu acervo permanente (do Museu Nacional de Arte Moderna - MNAM da França). Em 20 I5, seu acervo de arte moderna ganhou uma nova disposição. Com curadoria de Catherine Grénier, a exposição permanente do MNAM intitulada "Modernidades Plurais" causou enorme polêmica, ao propor um arranjo narrativo que incorporasse as alteridades - como no caso da sala dedicada à arquitetura moderna desenvolvida nas ex-colônias francesas durante o período colonial. Sua desmontagem, apenas I ano e meio depois de sua abertura, parece ser sintomática das tensões que o mundo vive desde os anos 1960, que pareciam superadas por novos protocolos assinados dentro dos órgãos culturais das Nações Unidas, com o advento do multiculturalismo e das teorias pós-colonialistas. De fato, paralelamente à emergência da nova noção de museu de arte, discutia-se, no campo da museologia, o papel social dos museus. A nova museologia nasceu justamente das discussões que levaram à famosa mesa de Santiago em 1972, que reavaliava o papel social dos museus e a reformulação desses espaços no sentido de melhor interargir com a sociedade e com as comunidades locais. Em 20 I5, mais um passo 
foi dado nessa direção, quando a UNESCO publicou a nova Recomendação referente à Proteção e Promoção dos Museus e Coleções, sua diversidade e seu papel na Sociedade, ampliando a noção de patrimônio e o papel social dos museus.

Ao que tudo indica, os museus de arte contemporânea são um fenômeno próximo dessas discussões e vem cada vez mais buscando ser espaços de interação e articulação com a sociedade, mas ainda enfrentam muitas contradições, que cada vez menos tem a ver com a dificuldade de acolhimento de novas práticas artísticas e de debate sobre alteridades - questões que tem sido bastante trabaIhadas pelos artistas e pelos curadores na contemporaneidade. Então, passados quase 50 anos, e da expansão das grandes mostras sazonais internacionais e do fenômeno da proliferação de museus de arte contemporânea nos mais diversos territórios, como pensar o museu de arte contemporânea no século 21 ? Como podemos lidar com as diferenças culturais nos mais variados continentes em face do fenômeno da arte global? Como colecionamos arte contemporânea, para quê e para quem o fazemos? Qual o papel da história da arte de um ponto de vista prospectivo?

Essas e outras perguntas foram propostas aos autores da coletânea de textos que veremos a seguir. Propusemos a eles que escrevessem a partir de sua experiência de pesquisa em história e crítica da arte, considerando também suas práticas curatoriais e/ou artísticas. Dessa espécie de enquete e da proposição feita a eles resultou uma constelação de textos que abrangem questões muito distintas sobre o museu de arte contemporânea hoje. Peter Schneemann propôs fazer um balanço sobre como o museu de arte contemporânea colecionou e documentou as práticas processuais e suas vicissitudes no contexto museológico, bem como seus desdobramentos atuais. Giselle Beiguelman nos fala do "museu da perda", ou no fato de que as mídias digitais levaram às questões do efêmero e dos modos de preservação das práticas artísticas ao extremo, ao mesmo tempo que inauguraram efetivamente outra concepção de objeto artístico. Ela ainda nos chama a atenção para o crescente sistema de controle dos meios virtuais, que fez com que produzir arte nestes meios tenha se tornado bem mais complexo. Manuela Naveau tratou da pesquisa artística, ou de como o campo da arte vem se apropriando de outras metodologias (tomadas das disciplinas científicas, já altamente especializadas) para criar proposições artísticas. Assim, ela nos leva a refletir sobre como essas proposições se configuram no espaço de exposição e como o museu de arte pode documentá-las e colecioná-las. Por sua vez, e de certa forma retomando uma tradição artística do século 20, Thierry Dufrêne debruçou-se sobre aquilo que, em francês, ele chama de "outras artes" e de modos de produção de objetos que tem uma incidência no campo da arte, mas que até muito recentemente não entravam plenamente na historiografia da arte. Por fim, o ensaio de Ivo Mesquita nos atenta para a inserção dos museus de arte no campo da indústria cultural e de como isso vem modificando as instituições artísticas, seus preceitos, bem como a produção artística ela mesma.

Com esse pequeno dossiê, esperamos contribuir para a reflexão sobre o museu de arte contemporânea como instituição (já) histórica, saindo da chave do problema de incorporação das novas práticas artísticas - que nos parece uma questão bastante discutida internacionalmente, mesmo que não completamente superada. Para além dessa, questões relativas ao trato com a produção artística, ao diálogo com os artistas e com o público, e sobretudo ao papel dos museus de arte como lugares de produção de conhecimento e de interação com a cultura local emergem. Talvez a questão de fundo que perpasse o dossiê seja ainda o valor simbólico atribuído ao museu de arte na sua fórmula de museu de arte contemporânea. 